\title{
Hepatic steatosis: a risk factor for increased COVID-19 prevalence and severity-a computed tomography study
}

\author{
Asmaa Ali, Mona Hasan, Shaimaa Hamed and Amir Elhamy
}

\begin{abstract}
Background: Around $25 \%$ of the world population was affected by the metabolic-related fatty liver disorder. Hepatic steatosis is frequently observed in conjunction with hypertension, obesity comorbidities, and diabetes. We evaluate the hepatic steatosis frequency found in chest CT exams of COVID-19-positive cases compared to noninfected controls and evaluate the related increased prevalence and severity of COVID.

Results: Our research includes 355 subjects, 158 with positive PCR for COVID-19 (case group) and 197 with negative PCR and negative $C T$ chest (control group). The mean age in the positive group was $50.6 \pm 16$ years, and in the control, it was $41.3 \pm 16$ years ( $p<0.001)$. Our study consists of 321 men $(90.5 \%)$ and 34 women $(9.5 \%)$. The number of males in both cases and control groups was greater. In the case group, 93\% men vs. 6.9\% women, while in controls, $88.3 \%$ men vs.11.6\% women, $\mathrm{p}<0.001$. CT revealed normal results in $55.5 \%$ of individuals (i.e., CORADs 1) and abnormal findings in $45.5 \%$ of participants (i.e., CORADs 2-5). In abnormal scan, CO-RADs 2 was 13.92\%, while CO-RADs 3-4 were $20.89 \%$ of cases. CO-RADs 5 comprised $65.19 \%$ of all cases. Approximately $42.6 \%$ of cases had severe disease (CT score $\geq 20$ ), all of them were CO-RADs 5. The PCR-positive class had a greater prevalence of hepatic steatosis than controls (28.5\% vs.12.2\%, $\mathrm{p}<0.001)$. CO-RADs 2 represented $11.1 \%$, CO-RADs 3-4 represented $15.6 \%$, and CO-RADs 5 represented $73.3 \%$ in the hepatic steatosis cases. The mean hepatic attenuation value in the case group was $46.79 \pm 12.68$ and in the control group $53.34 \pm 10.28(p<0.001)$. When comparing patients with a higher severity score (CT score $\geq 20)$ to those with non-severe pneumonia, it was discovered that hepatic steatosis is more prevalent $(73.2 \%$ vs. $26.8 \%)$.
\end{abstract}

Conclusions: Steatosis was shown to be substantially more prevalent in COVID-19-positive individuals. There is a relation among metabolic syndrome, steatosis of the liver, and obesity, as well as the COVID-19 severity.

Keywords: Fatty liver, Computed tomography, COVID-19

\section{Key points}

- High-resolution computed tomography aids clinicians in evaluating lung affection in COVIDpositive cases.

- Fatty liver and obesity are rising globally.
- Fatty liver and metabolic syndrome are significant predisposing parameters for COVID-19 infection and increase disease's severity.

\section{Background}

The World Health Organization declared coronavirus disease 2019 (COVID-19) as a pandemic on March 11, 2020 [1]. By May 2021, around 165,772,430 reported cases and 3,437,545 mortalities had occurred (https:// www.who.org). COVID-19 is symptomatized by fever and dry cough, and the infection is diagnosed by a real-

\footnotetext{
*Correspondence: asmaa_monir@hotmail.com

Theodor Bilharz Institute, Kornish Elnil, Embaba, Giza, Egypt
}

(c) The Author(s). 2021 Open Access This article is licensed under a Creative Commons Attribution 4.0 International License, which permits use, sharing, adaptation, distribution and reproduction in any medium or format, as long as you give appropriate credit to the original author(s) and the source, provide a link to the Creative Commons licence, and indicate if changes were made. The images or other third party material in this article are included in the article's Creative Commons licence, unless indicated otherwise in a credit line to the material. If material is not included in the article's Creative Commons licence and your intended use is not permitted by statutory regulation or exceeds the permitted use, you will need to obtain permission directly from the copyright holder. To view a copy of this licence, visit http://creativecommons.org/licenses/by/4.0/. 
time reverse transcription-polymerase chain reaction (RT-PCR) test [2, 3]. Due to the rise in global cases, other symptoms like constipation, diarrhea, abdominal pain, and vomiting have risen; these are associated with abnormal renal and liver functions, and D-Dimer levels $[4,5]$

COVID-19 can impact other organs besides the respiratory system, like the cardiovascular system, kidneys, liver, and coagulation system [6-10].

Diabetes, age, metabolic syndrome, hypertension, and obesity are all risk parameters for severe/critical illness and death [11-13].

People with obesity and type 2 diabetes are at greater risk for non-alcoholic fatty liver disease NAFLD, that worsen these disorders. It has been linked to an inflammatory response (increased neutrophil-to-lymphocyte ratio [NLR]) and subsequent poor outcomes in COVID19-infected cases [14].

NAFLD has risen over the last two decades, affecting around $24 \%$ of the individual $[15,16]$. NAFLD is a complex process with hepatic and extrahepatic pathophysiology and clinical symptoms. It leads to ectopic fatty substrate deposits in the liver, ranging from simple steatosis without inflammation to steatohepatitis, which causes cirrhosis and fibrosis [15].

CT affects the care of COVID-19 individuals because it aids in the early discovery and diagnosis, particularly in cases when the RT-PCR result is false-negative [16].

COVID-19 chest CT results are typically multifocal bilateral, mostly peripheral subpleural round, ground-glass opacities with or without patchy consolidations affecting mostly the posterior lower lobes [17]. Additionally, airway changes, reversed halo sign, and crazy paving patterns can be detected [18]. The Radiological Society of North America (RSNA) defined four categories on reporting chest CT findings in COVID-19 pneumonia: (1) typical features that are usually reported in COVID19, (2) indeterminate features that are not characteristic of COVID-19 pneumonia, (3) atypical features that are uncommon in COVID-19 pneumonia but can occur with other infections, and (4) negative for lung inflammation with no lung results denoting infection. Chest CT may be negative in the early stages of COVID-19 infection [19].

We frequently include the upper abdomen in the regular CT scan of the chest conducted to assess cases with COVID-19 pneumonia, so that most of the liver and spleen can be viewed and examined [20].

The regular liver appears slightly more attenuated on non-contrast CT than the blood and spleen, and the intrahepatic arteries present as hypo-attenuated structures. Although histopathological analysis and liver biopsy are the gold measure for determining hepatic steatosis, they are invasive procedures. As a result, numerous studies have examined non-invasive alternatives to liver biopsy utilizing CT imaging [21].

Unenhanced CT liver attenuation alone is highly specific for moderate to severe hepatic steatosis, obviating the requirement for verification by biopsy [22].

Numerous approaches have been used for evaluating hepatic steatosis by computed tomography; the most important of which is determining the liver's attenuation value. In the non-enhanced phase, the region of interest is set in the right hepatic lobe; if it is less than $40 \mathrm{HU}$, this indicates moderate hepatic steatosis with a fat liver percentage greater than $30 \%$ [23, 24]. Another way for assessing hepatic steatosis is to compare the area of interest in the splenic parenchyma to the liver, when we find the attenuation of liver is at least $10 \mathrm{HU}$ less than that of the spleen. Several studies have demonstrated that non-enhanced CT has a great sensitivity (from 43 to $95 \%$ ) and a great specificity (from 90 to $100 \%$ ) for detecting hepatic steatosis [25-27].

\section{Methods}

This retrospective study was conducted at our institution's Radiology Department from May 1, 2020, to June 1, 2020. Approval was acquired from the Institution's Ethics and Research Committee. Informed consent was taken.

\section{Inclusion criteria}

Our research included 355 subjects who presented with flu-like symptoms and were suspected of being infected with COVID-19. They underwent PCR checking and chest CT for COVID-19. For all, we utilize the same 64slice CT scanner (Siemens Healthcare, Germany).

The case group included 158 subjects (PCR positive for COVID-19), while the control group consisted of 197 subjects with a negative PCR test. It is widely established that false-negative RT-PCR can happen in infected individuals, but CT chest may reveal disease signs (positive CT). Therefore, to ensure the control group's negativity, we checked their CT chest and retained only those who had a negative CT chest (PCR-negative and chest CT-negative pattern).

Two radiologists with over 10 years of expertise interpreted the CT chest.

CT evaluation involved identifying the areas of ground-glass opacities, crazy-paving patterns (groundglass opacities with interlobular septal thickening), atelectatic bands, and consolidations. CT results were divided into five classes using the RSNA Expert Consensus Criteria [28], as well as the COVID-19 Reporting and Data System (CO-RADs) from the COVID-19 Working Group of the Dutch Radiological Society [29]. CT results are graded according to these grading methods as normal, inconsistent, or typical of COVID-19 pneumonia. 
The severity of lung affection (CT severity index) was measured as per Yang et al. A CT score of more than $20 / 40$ indicates serious illness and is typically related to a poor prognosis [30].

We assess hepatic steatosis in our research by determining the attenuation of liver value. The area of interest (with an average area of $10 \mathrm{~cm}^{2}$ ) was located in the right hepatic lobe (between segments VI and VII), chosen area away from the biliary tree, vessels, or focal lesions. We examine one slice and define the liver as fatty if the HU reading is less than 40 .

\section{Statistical analysis}

SPSS (Statistical Package for the Social Sciences; SPSS Inc., Chicago, IL, USA) release 25 was utilized for all statistical calculations. Standard deviations and means are used to describe quantitative data, while percentages are used to indicate qualitative data. Per the variable distribution, we employed the t-Student and chi-square checks. A p-value below 0.05 was considered significant.

\section{Results}

\section{Characteristics of study group (Table 1)}

- Our research includes 355 subjects, 158 with positive PCR for COVID-19 (case group) and 197 with negative PCR and negative CT chest (control group). The mean age in the positive group was 50.6 \pm 16 years, and in the control, it was $41.3 \pm 16$ years ( $\mathrm{p}<0.001)$.

- Our study comprised 321 men (90.5\%) and 34 women (9.5\%). The number of males in both cases and control groups was greater. In the case group, $93 \%$ men vs. $6.9 \%$ women, while in controls, $88.3 \%$ men vs.11.6\% women, $\mathrm{p}<0.001$.

- CT demonstrated normal results in $55.5 \%$ of individuals (i.e., CORADs 1 ) and abnormal findings in $45.5 \%$ of participants (i.e., CORADs $2-5$ ). In abnormal scan, CO-RADs 2 was 13.92\%, while CO-
RADs 3-4 were $20.89 \%$ of cases. CO-RADs 5 comprised $65.19 \%$ of all cases. Approximately $42.6 \%$ of cases had severe disease (CT score $\geq 20$ ); all of them were CO-RADs 5.

\section{Association with steatosis (Figs. 1, 2, 3, 4, and 5)}

- The PCR-positive group had a greater prevalence of hepatic steatosis than controls (28.5\% vs.12.2\%, p < 0.001). CO-RADs 2 represented 11.1\%, CO-RADs 3-4 represented $15.6 \%$, and CO-RADs 5 represented $73.3 \%$ in the hepatic steatosis cases.

- The mean hepatic attenuation value in the case group was $46.79 \pm 12.68$, and in the control group, $53.34 \pm 10.28(\mathrm{p}<0.001)$.

- When comparing patients with a higher severity score (CT score $\geq 20$ ) to those with non-severe pneumonia, it was discovered that hepatic steatosis is more prevalent ( $73.2 \%$ vs. $26.8 \%)$.

\section{Discussion}

In 2016, the World Health Organization reported that 1.9 billion adults were overweight, with over 650 million being obese [31]. Obesity is the most major and significant risk factor in developing hepatic steatosis in adults and children [32].

Obesity is thought to be a condition of low-grade systemic inflammation that has been linked to a variety of metabolic diseases like type 2 diabetes mellitus and dyslipidemia. It can alter immunological responses, causing the immune system more sensitive to infection development [33].

Due to its endocrine roles and the release of various adipokines and proinflammatory cytokines like leptin, interleukin 6, C-reactive protein, visceral adipose tissue, and TNF are more metabolically active than subcutaneous adipose tissue $[34,35]$. It is well documented that raised IL-6 levels are related to chronic inflammatory airway disorder. Numerous studies have discovered

Table 1 Demographic comparison parameters and statistics between the two groups

\begin{tabular}{lll}
\hline Parameter & $\begin{array}{l}\text { Case group } \\
\text { Positive PCR } \\
\mathbf{N}=\mathbf{1 5 8}\end{array}$ & $\begin{array}{l}\text { Control group } \\
\text { Negative PCR/negative chest CT } \\
\mathbf{N}=\mathbf{1 9 7}\end{array}$ \\
\hline Age & $50.6 \pm 16$ years & $41.3 \pm 16$ years \\
Sex & & $\mathrm{N}=174(88.3 \%)$ \\
$\quad$ Male & $\mathrm{N}=147(93 \%)$ & $\mathrm{N}=23(11.6 \%)$ \\
$\quad$ Female & $\mathrm{N}=11(6.9 \%)$ & $12.2 \%$ \\
Steatosis & $28.5 \%$ & $53.34 \pm 10.28$ \\
HU & $46.79 \pm 12.68$ & CO-RADs $1, \mathrm{~N}=197(55.5 \%)$ \\
CO-RADs & CO-RADs 2, N $=22(13.92 \%)$ & \\
& CO-RADs 3-4, N = 33(20.89\%) \\
\hline
\end{tabular}



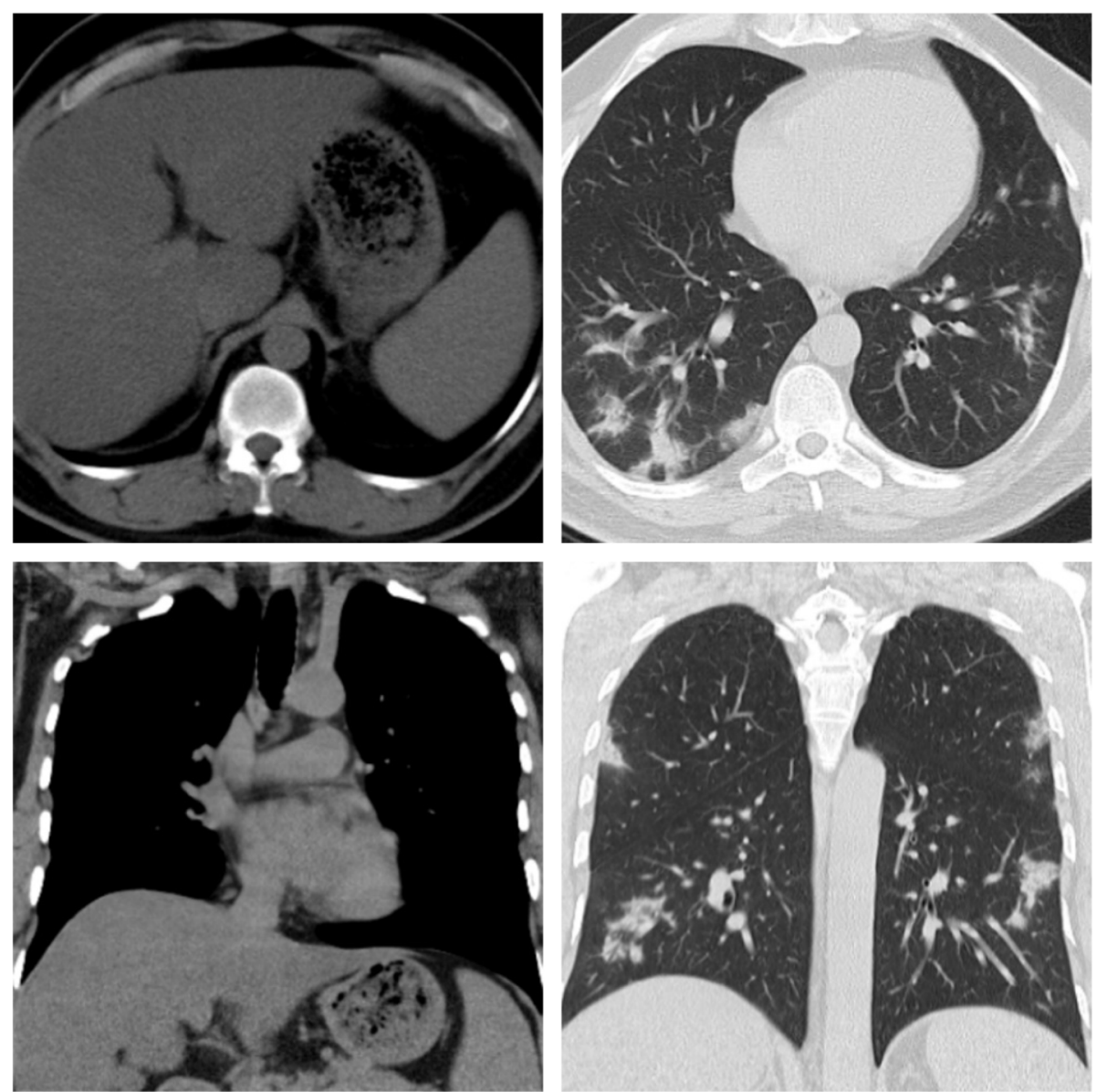

Fig. 1 Male patient, 45 years old. CT chest shows multiple bilateral pulmonary patchy ground-glass opacities, reported as CORADs 5. Upper abdominal cuts show hepatic steatosis

greater IL-6 concentrations in post-mortem specimens from COVID-19 cases [36, 37]. Leptin has been linked with airway reactivity, and current research indicates that leptin concentrations are increased in COVID-19 cases with significant pulmonary inflammation $[38,39]$.
COVID-19 invades human cells through binding with angiotensin-converting enzyme 2, and some research shows that the renin-angiotensin-aldosterone system's imbalanced activity in obese individuals contributes to this pathogenesis. Because ACE2 expression is greater in adipose tissue than in lung tissue, and because ACE2 in

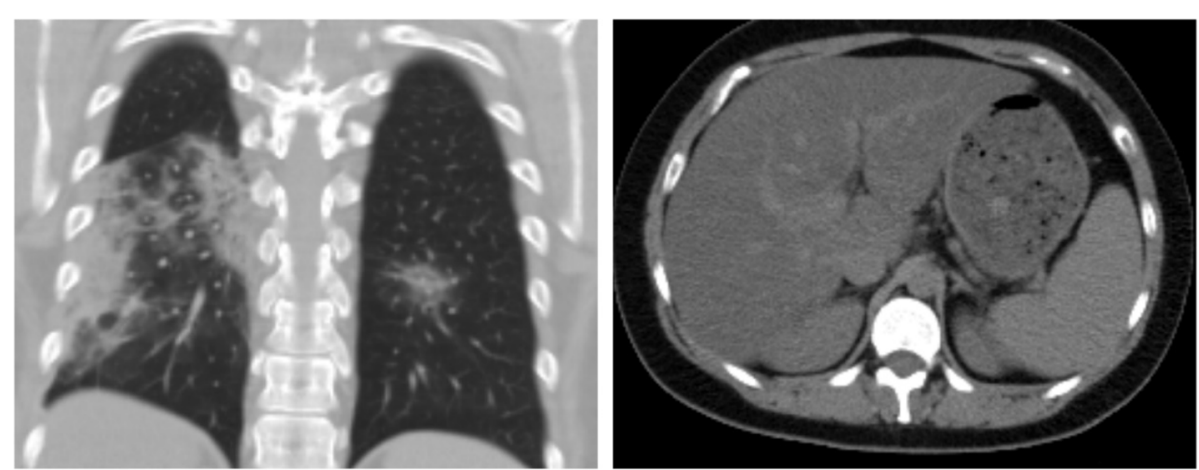

Fig. 2 Female patient, 28 years old. CT chest shows multiple pulmonary ground-glass opacities mounting to consolidative patches, reported as CORADs 5. Upper abdominal cuts show diffuse low parenchymal attenuation of the liver denoting fatty infiltration 

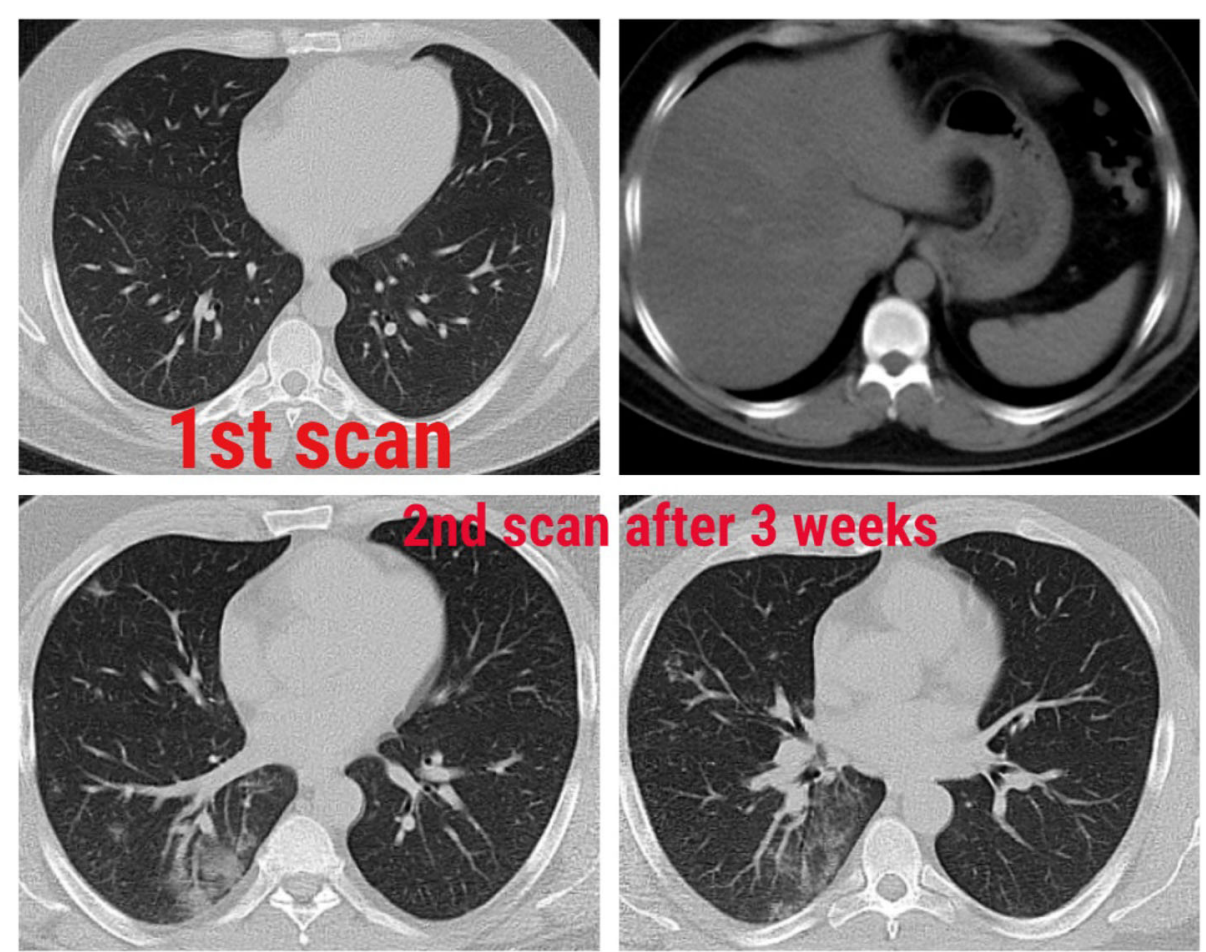

Fig. 3 Male patient, 36 years old. The first scan after few days of symptoms shows just a small patchy ground-glass opacity in the middle lobe. The second scan after 3 weeks for follow-up shows a progressive course with multiple pulmonary ground-glass opacities. CT cuts of the upper abdomen show a fatty liver
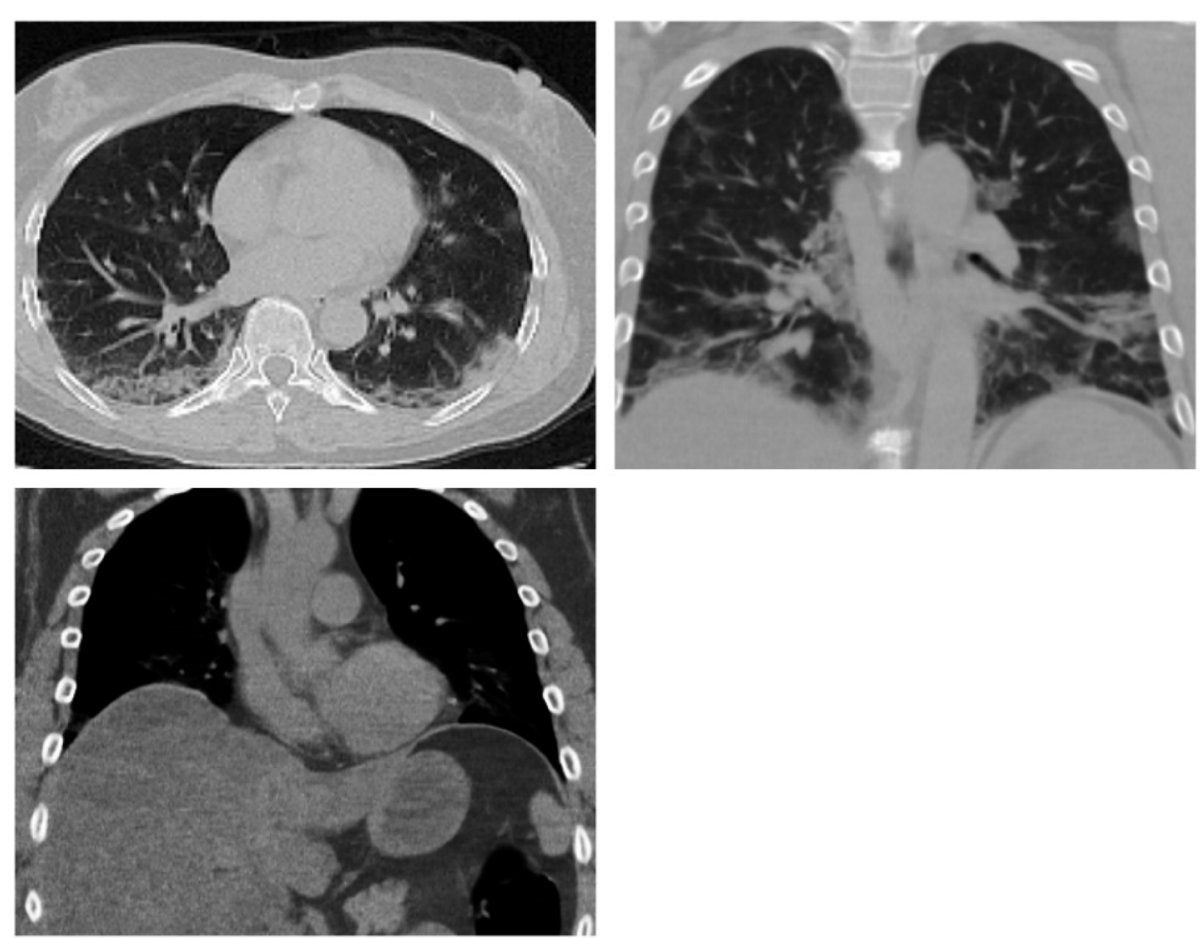

Fig. 4 Male patient, 64 years. CT chest shows bilateral lower lobar subpleural patchy ground-glass opacities with underlying interlobular septal thickening and atelectatic bands, reported as CORADs 5. Upper abdominal cuts show fatty hepatomegaly 

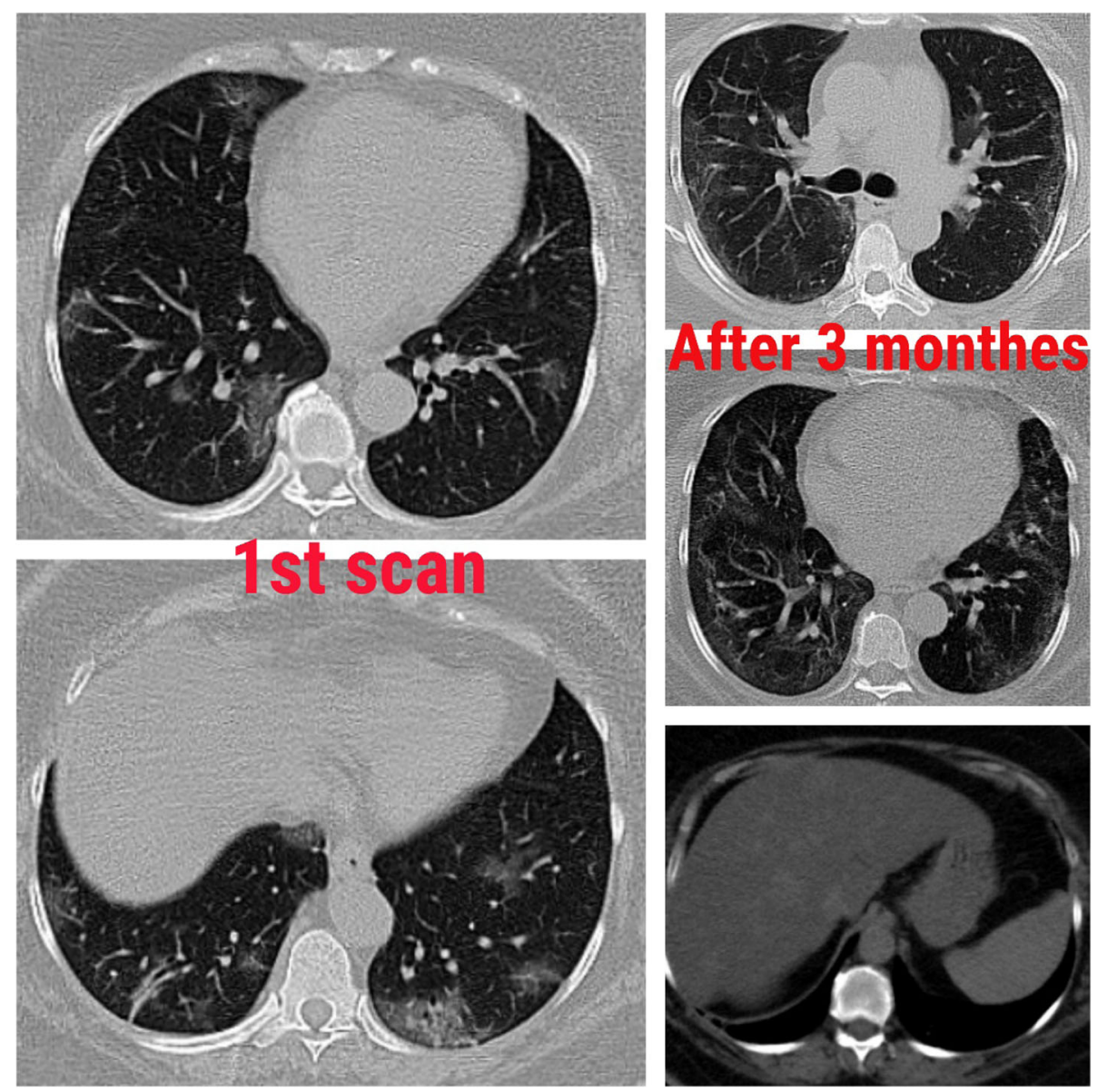

Fig. 5 Female patient, 58 years old. The first scan shows multiple subpleural ground-glass opacities on follow-up after 3 months. CT shows multiple subpleural parenchymal bands. Upper abdominal cuts show fatty hepatomegaly

lung tissue is known to be the primary entry point for SARS-CoV-2, this increases the sensitivity of obese patients to infection [40].

Additionally, obese individuals have impaired $\mathrm{B}$ and $\mathrm{T}$ cell responses due to changes in the quantity and function of lymphocytes, resulting in an increased vulnerability to viral infection. In virally infected obese individuals, the inflammatory response is dysregulated, resulting in a reduction and delay in macrophage activation [41]. Obesity can promote antiviral resistance as well [42].

NLR, a measure of systemic inflammation, was considerably elevated and related to poorer results in cases infected with COVID-19 [43]. There is a substantial correlation between this ratio and the severity of liver fibrosis in people with NAFLD. Current research has established that this association affects the COVID-19induced inflammatory storm, which is associated with raised death and morbidity. In cases infected with COVID-19, liver injury occurs following lung injury [44]. This destruction could be caused by the overactivation of Kupffer cells, the production of a cytotoxic $\mathrm{T}$ cell response produced by the virus, or the production of a dysregulated innate immune response [45]. In these cases, post-mortem liver biopsies revealed microvascular steatosis [44].

According to Zheng et al., individuals with metabolicassociated fatty liver disease and obesity had a sixfold raised chance of developing severe COVID-19 infection [46]. Another research indicated that populations with metabolically related fatty liver disease (MAFLD) have a fourfold greater risk of developing severe forms of COVID-19 [47].

Per Palomar-Lever et al.'s findings, the combination of obesity and hepatic steatosis led to a significant relationship with serious illness, implying a synergic connection between both [20].

Medeiros et al. concluded that the steatosis prevalence on CT was greater in confirmed COVID pneumonia cases than in the control. This is important for radiologists because liver steatosis can be easily assessed and 
verified by any radiologist reading a chest CT. Moreover, this data can be added to the clinical data available to clinicians [48].

In research conducted in New York, cases with a body mass index (BMI) of $\geq 30$ had a higher chance of acute care hospitalization, and those with a BMI of $\geq 35$ had a higher risk of intensive care unit admission [49].

Additionally, it was observed that cases with NAFLD had a greater rate of progression to severe illness and poorer findings in COVID19 [44, 50, 51].

Ji et al. studied NAFLD in 202 cases with COVID-19 using the hepatic steatosis index based on ALT, AST, body mass index, gender, presence of diabetes, and/or an ultrasound examination. They discovered that preexisting comorbidities and NAFLD were linked with COVID-19 progression [44].

According to Zhou et al., the risk of severe COVID-19 increases fourfold when metabolic-related fatty liver disease is present [52].

As with the previous research, univariate and multivariate analyses suggested that individuals with NAFLD had an increased risk of disease progression. Comorbidities like diabetes mellitus, hypertension, coronary artery disease, and COPD are identified as additional risk parameters for COVID-19 progression [44, 53].

Petersen et al. used low-dose computed tomography and post-processing software to measure body fat distribution particularly visceral adipose tissue and upper abdominal circumference in COVID patients and found that these two parameters significantly increase the likelihood of COVID-19 severe courses [54].

Parlak et al. found that chest $\mathrm{CT}$, which is critical for diagnosing COVID-19, can provide data about the disease's prognosis and that fatty liver is a significant indicator of a bad prognosis and may be easily spotted on chest CT used for COVID-19 diagnosis [55].

\section{Limitations}

Other significant variables like hypertension, lipid profile, diabetes, weight, obesity, body mass index, and liver function were not evaluated. Hence, a correlation between these variables and hepatic steatosis could not be established.

\section{Conclusion}

In confirmed COVID-19 cases, our research demonstrates a considerably greater frequency of hepatic steatosis by CT as compared to controls. There is a correlation among metabolic syndrome, steatosis of the liver, and obesity, as well as the severity of COVID-19.

\section{Abbreviations}

RT-PCR: Real-time reverse transcription polymerase chain reaction; COVID19: Coronavirus disease of 2019; MAFLD: Metabolic fatty liver disease; NLR: Neutrophil-to-lymphocyte ratio; NAFLD: Non-alcoholic fatty liver disease;
IL-6: Interleukin 6; HU: Hounsfield unit; SARS-CoV-2: Severe acute respiratory syndrome coronavirus 2; ACE2: Angiotensin-converting enzyme 2;

HS: Hepatic steatosis

\section{Acknowledgements}

Not applicable.

\section{Authors' contributions}

AA wrote the manuscript and was responsible for the correspondence to the journal. MH collected the patient data and participated in its design. SH contributed to the image processing and collection of the patient's images. AE participated in the design of the study, performed the statistical analysis and participated in its design and coordination, and helped to draft the manuscript.All authors have read and approved the final manuscript.

\section{Funding}

This work has not received any funding sources.

\section{Availability of data and materials}

The datasets used and analyzed during the current study are available from the corresponding author on reasonable request.

\section{Declarations}

Ethics approval and consent to participate

The study was approved by the ethical committee of "Theodor Bilharz Institute" institutional review board with ethical committee approval number FWA 10609. An informed written consent was taken from all patients.

\section{Consent for publication}

An informed written consent was taken from all subjects.

\section{Competing interests}

The authors declare that they have no competing interests.

Received: 9 April 2021 Accepted: 20 June 2021

Published online: 12 July 2021

\section{References}

1. Watanabe M, Risi R, Tuccinardi D, Baquero CJ, Manfrini S, Gnessi L (2020) Obesity and SARS-CoV-2: a population to safeguard. Diabetes Metab Res Rev. https://doi.org/10.1002/dmrr.3325

2. Kanne JP (2020) Chest CT findings in 2019 novel coronavirus (2019-nCoV infections from Wuhan, China: key points for the radiologist. Radiology 295(1):16-17. https://doi.org/10.1148/radiol.2020200241

3. Yoon SH, Lee KH, Kim JY, Lee YK, Ko H, Kim KH, Park CM, Kim YH (2020) Chest radiographic and CT findings of the 2019 novel coronavirus disease (COVID-19): analysis of nine patients treated in Korea. Korean J Radiol 21: 494-500. https://doi.org/10.3348/kjr.2020.0132

4. Cholankeril G, Podboy A, Aivaliotis VI, Tarlow B, Pham EA, Spencer SP, Kim D, Hsing A, Ahmed A (2020) High prevalence of concurrent gastrointestinal manifestations in patients with SARS-CoV-2: early experience from California. Gastroenterology. 159(2):775-777. https://doi.org/10.1053/j.gastro.2020.04. 008

5. Luo S, Zhang X, Xu H (2020) Don't overlook digestive symptoms in patients with 2019 novel coronavirus disease (COVID-19). Clin Gastroenterol Hepatol 18(7):1636-1637. https://doi.org/10.1016/j.cgh.2020.03.043

6. Han H, Xie L, Liu R et al (2020) Analysis of heart injury laboratory parameters in 273 COVID-19 patients in one hospital in Wuhan, China [published online ahead of print, 2020 march 31]. J Med Virol. https://doi.org/10.1002/jmv.2 5809

7. Ammirati E, Wang DW (2020) SARS-CoV-2 inflames the heart. The importance of awareness of myocardial injury in COVID-19 patients [published online ahead of print, 2020 April 6]. Int J Cardiol S01675273(20)31669-7. https://doi.org/10.1016/j.ijcard.2020.03.086

8. Zhang C, Shi L, Wang FS (2020) Liver injury in COVID-19: management and challenges. Lancet Gastroenterol Hepatol 5(5):428-430. https://doi.org/10.1 016/S2468-1253(20)30057-1

9. Durvasula R, Wellington T, McNamara E, Watnick S (2020) COVID-19 and kidney failure in the acute care setting: our experience from Seattle 
[published online ahead of print, 2020 April 7]. Am J Kidney Dis S02726386(20)30618-1. https://doi.org/10.1053/.jajkd.2020.04.001

10. Dolhnikoff M, Duarte-Neto AN, de Almeida Monteiro RA et al (2020) Pathological evidence of pulmonary thrombotic phenomena in severe COVID-19 [published online ahead of print, 2020 April 15]. J Thromb Haemost. https://doi.org/10.1111/jth.14844

11. Wu Z, McGoogan JM (2020) Characteristics of and important lessons from the coronavirus disease 2019 (COVID-19) outbreak in China: summary of a report of 72314 cases from the Chinese Center for Disease Control and Prevention. JAMA. 323(13):1239-1242. https://doi.org/10.1001/jama.2020.264 8

12. Mantovani A, Byrne CD, Zheng MH, Targher G (2020) Diabetes as a risk factor for greater COVID-19 severity and in-hospital death: a meta-analysis of observational studies. Nutr Metab Cardiovasc Dis 30(8):1236-1248. https://doi.org/10.1016/j.numecd.2020.05.014

13. Targher $G$, Mantovani A, Wang XB, Yan HD, Sun QF, Pan KH, Byrne CD, Zheng Kl, Chen YP, Eslam M, George J, Zheng MH (2020) Patients with diabetes are at higher risk for severe illness from COVID-19. Diabetes Metab 46(4):335-337. https://doi.org/10.1016/j.diabet.2020.05.001 In press

14. Targher $G$, Mantovani $A$, Byrne $C D$, Wang XB, Yan $H D$, Sun $Q F$, Pan $K H$, Zheng Kl, Chen YP, Eslam M, George J, Zheng MH (2020) Detrimental effects of metabolic dysfunction-associated fatty liver disease and increased neutrophil-to-lymphocyte ratio on severity of COVID-19. Diabetes Metab 46(6):505-507. https://doi.org/10.1016/j.diabet.2020.06.001 In press

15. Angulo P (2002) Nonalcoholic fatty liver disease. N Engl J Med 346(16): 1221-1231. https://doi.org/10.1056/NEJMra011775

16. Yang W, Sirajuddin A, Zhang X, Liu G, Teng Z, Zhao S et al (2020) The role of imaging in 2019 novel coronavirus (COVID-19). Eur Radiol. https://doi. org/10.1007/s00330-020-06827-4

17. Zu ZY, Jiang MD, Xu PP, Chen W, Ni QQ, Lu GM, Zhang L (2020) Coronavirus disease 2019 (COVID-19): a perspective from China. Radiology 296(2):E15-E25. https://doi.org/10.1148/radiol.2020200490

18. Ye Z, Zhang Y, Wang Y, Huang Z, Song B (2020) Chest CT manifestations of new coronavirus disease 2019 (COVID-19): a pictorial review. Eur Radiol 30(8):4381-4389. https://doi.org/10.1007/s00330-020-06801-0

19. Simpson S, Kay FU, Abbara S, Bhalla S, Chung JH, Chung M, Henry TS, Kanne JP, Kligerman S, Ko JP, Litt H (2020) Radiological Society of North America expert consensus statement on reporting chest $C T$ findings related to COVID-19. Endorsed by the Society of Thoracic Radiology, the American College of Radiology, and RSNA. Radiol Cardiothoracic Imaging 2(2):e200152

20. Palomar-Lever A, Barraza G, Galicia-Alba J, Echeverri-Bolaños M, EscarriaPanesso R, Padua-Barrios J, Halabe-Cherem J, Hernandez-Molina G, ChargoyLoustaunau TN, Kimura-Hayama E (2020) Hepatic steatosis as an independent risk factor for severe disease in patients with COVID-19: a computed tomography study. JGH Open 4(6):1102-1107. https://doi.org/1 $0.1002 / \mathrm{jgh} 3$

21. Hamer OW, Aguirre DA, Casola G, Sirlin CB (2005) Imaging features of perivascular fatty infiltration of the liver: initial observations. Radiology 237: 159-169. https://doi.org/10.1148/radiol.2371041580

22. Pickhardt PJ, Park SH, Hahn L, Lee SG, Bae KT, Yu ES (2012) Specificity of unenhanced $C T$ for non-invasive diagnosis of hepatic steatosis: implications for the investigation of the natural history of incidental steatosis. Eur Radiol 22(5):1075-1082. https://doi.org/10.1007/s00330-011-2349-2

23. Lawrence DA, Oliva IB, Israel GM (2012) Detection of hepatic steatosis on contrast-enhanced $C T$ images: diagnostic accuracy of identification of areas of presumed focal fatty sparing. Am J Roentgenol 199:44-47. https://doi. org/10.2214/AJR.11.7838

24. Wells MM, Li Z, Addeman B, Mckenzie CA, Mujoomdar A, Beaton M et al (2016) Computed tomography measurement of hepatic steatosis: prevalence of hepatic steatosis in a Canadian population. Can J Gastroenterol Hepatol 2016:4930987. https://doi.org/10.1155/2016/4930987

25. Monjardim RDF, Costa DMC, Romano RFT, Salvadori PS, dos Santos J, de VC VAAC et al (2013) Diagnosis of hepatic steatosis by contrast-enhanced abdominal computed tomography. Radiol Bras 46:134-138. https://doi.org/1 0.1590/S0100-39842013000300005

26. Ma X, Holalkere NS, Avinash KR, Mino-Kenudson M, Hahn PF, Sahani DV (2009) Imaging-based quantification of hepatic fat: methods and clinical applications. Radiographics 29:1253-1277. https://doi.org/10.1148/rg.2 95085186

27. Boyce CJ, Pickhardt PJ, Kim DH, Taylor AJ, Winter TC, Bruce RJ et al (2010) Hepatic steatosis (fatty liver disease) in asymptomatic adults identified by unenhanced low-dose CT. Am J Roentgenol 194:623-628. https://doi.org/1 0.2214/AJR.09.2590

28. Simpson S, Kay FU, Abbara S, Bhalla S, Chung JH, Chung M (2020) Radiological Society of North America expert consensus statement on reporting chest CT findings related to COVID-19. Endorsed by the Society of Thoracic Radiology, the American College of Radiology, and RSNA. Radiology 2:2. https://doi.org/10.1148/ryct.2020200152

29. Prokop M, van Everdingen W, van Rees VT, Jet Quarles van Ufford JT, Stöger L et al (2020) CO-RADS - a categorical CT assessment scheme for patients with suspected COVID-19: definition and evaluation. Radiology. https://doi. org/10.1148/radiol.2020201473

30. Yang R, Li X, Liu H et al (2020) Chest CT severity score: an imaging tool for assessing severe COVID-19. Radiology 2:2. https://doi.org/10.1148/ryct.20202 00047

31. Hill JJ (2018) Obesity: an emerging threat. J Natl Black Nurses Assoc 29(2): 36-39

32. Festi D, Colecchia A, Sacco T, Bondi M, Roda E, Marchesini G (2004) Hepatic steatosis in obese patients: clinical aspects and prognostic significance. Obes Rev 5:27-42. https://doi.org/10.1111/j.1467-789x.2004.00126.x

33. Dhurandhar NV, Bailey D, Thomas D (2015) Interaction of obesity and infections. Obes Rev 16(12):1017-1029. https://doi.org/10.1111/obr.12320

34. Muscogiuri G, Pugliese G, Barrea L, Savastano S, Colao A (2020) Comentary: obesity: the "Achilles heel" for COVID-19? Metabolism. 108:154251. https:// doi.org/10.1016/j.metabol.2020.154251

35. Ritter A, Friemel A, Fornoff F, Adjan M, Solbach C, Yuan J, Louwen F (2015) Characterization of adipose-derived stem cells from subcutaneous and visceral adipose tissues and their function in breast cancer cells. Oncotarget. 6(33):34475-34493. https://doi.org/10.18632/oncotarget.5922

36. Zhou F, Yu T, Du R, Fan G, Liu Y, Liu Z et al (2020) Clinical course and risk parameters for mortality of adult inpatients with COVID-19 in Wuhan, China: a retrospective cohort study. Lancet. 395(10229):1054-1062. https://doi.org/1 0.1016/S0140-6736(20)30566-3

37. Park YS, Kwon HT, Hwang SS, Choi SH, Cho YM, Lee J, Yim JJ (2011) Impact of visceral adiposity measured by abdominal computed tomography on pulmonary function. J Korean Med Sci 26(6):771-777. https://doi.org/10.334 6/jkms.2011.26.6.771

38. Sideleva O, Suratt BT, Black KE, Tharp WG, Pratley RE, Forgione P, Dienz O, Irvin CG, Dixon AE (2012) Obesity and asthma: an inflammatory disease of adipose tissue not the airway. Am J Respir Crit Care Med 186(7):598-605. https://doi.org/10.1164/rccm.201203-05730C

39. Bourgonje AR, Abdulle AE, Timens W, Hillebrands JL, Navis GJ, Gordijn SJ et al (2020) Angiotensin-converting enzyme 2 (ACE2), SARS-CoV-2 and the pathophysiology of coronavirus disease 2019 (COVID-19). J Pathol Ahead of print

40. Lavie CJ, Sanchis-Gomar F, Henry BM, Lippi G (2020) COVID-19 and obesity: links and risks. Expert Rev Endocrinol Metab. https://doi.org/10.1080/1744 6651.2020 .1767589

41. Kim J, Nam JH (2020) Insight into the relationship between obesity induced low-level chronic inflammation and COVID-19 infection. Int J Obes 44(7): 1541-1542. https://doi.org/10.1038/s41366-020-0602-y

42. Petrakis D, Margină D, Tsarouhas K, Tekos F, Stan M, Nikitovic D et al (2020) Obesity - a risk factor for increased COVID-19 prevalence, severity and lethality (review). Mol Med Rep 22:9-19. https://doi.org/10.3892/mmr.202 0.11127

43. Lagunas-Rangel FA (2020) Neutrophil-to-lymphocyte ratio and lymphocyteto-C-reactive protein ratio in patients with severe coronavirus disease 2019 (COVID-19): a meta-analysis. J Med Virol 92(10):1733-1734. https://doi.org/10.1002/jmv.25819 In press

44. Ji D, Qin E, Xu J et al (2020) Non-alcoholic fatty liver diseases in patients with COVID-19: a retrospective study. J Hepatol 8:451-453

45. Wieckowska A, Papouchado BG, Li Z, Lopez R, Zein NN, Feldstein AE (2008) Increased hepatic and circulating interleukin-6 levels in human nonalcoholic steatohepatitis. Am J Gastroenterol 103(6):1372-1379. https://doi. org/10.1111/j.1572-0241.2007.01774.x

46. Zheng Kl, Gao F, Wang XB, Sun QF, Pan KH, Wang TY et al (2020) Obesity as a risk factor for greater severity of COVID-19 in patients with metabolic associated fatty liver disease. Metabolism. 2020;108:154244.

47. Gao F, Zheng Kl, Wang X-B, Yan H-D, Sun Q-F, Pan K-H et al (2020) Metabolic associated fatty liver disease increases COVID-19 disease severity in non-diabetic patients. J Gastroenterol Hepatol. https://doi.org/10.1111/ jgh.15112 
48. Medeiros AK, Barbisan CC, Cruz IR, Araújo EM, Libânio BB, Albuquerque KS, Torres US (2020) Higher frequency of hepatic steatosis at CT among COVID19-positive patients. Abdom Radiol (NY) 45(9):2748-2754. https://doi.org/1 0.1007/s00261-020-02648-7 Epub 2020 July 18

49. Lighter J, Phillips M, Hochman S, Sterling S, Johnson D, Francois F et al (2020) Obesity in patients younger than 60 years is a risk factor for Covid-19 hospital admission. Clin Infect Dis 15:2019-2020. https://doi.org/10.1093/cid/ ciaa4

50. Cai Q, Huang D, Ou P, Yu H, Zhu Z, Xia Z, Su Y, Ma Z, Zhang Y, Li Z, He Q, Liu L, Fu Y, Chen J (2020) COVID-19 in a designated infectious diseases hospital outside Hubei Province, China. Allergy 75(7):1742-1752. https://doi. org/10.1111/all.14309

51. Garrido I, Liberal R, Macedo G (2020) Review article: COVID-19 and liver disease-what we know on may 1 2020. Aliment Pharmacol Ther 52(2):267275. https://doi.org/10.1111/apt.15813

52. Zhou YJ, Zheng KI, Wang XB, Sun QF, Pan KH, Wang TY, Ma HL, Chen YP, George J, Zheng MH (2020) Metabolic-associated fatty liver disease is associated with severity of COVID-19. Liver Int 40(9):2160-2163. https://doi. org/10.1111/liv. 14575

53. Portincasa P, Krawczyk M, Smyk W, Lammert F, Di Ciaula A (2020) COVID-19 and non-alcoholic fatty liver disease: two intersecting pandemics. Eur J Clin Investig 50:e13338

54. Petersen A, Bressem K, Albrecht J, Thieß H, Vahldiek J, Hamm B, Makowski M, Niehues A, Niehues S, Adams L (2020) The role of visceral adiposity in the severity of COVID-19: highlights from a unicenter cross-sectional pilot study in Germany. Metabolism. 110:154317. https://doi.org/10.1016/j.meta bol.2020.154317

55. Parlak S, Çıvgın E, Beşler MS, Kayıpmaz AE (2021) The effect of hepatic steatosis on COVID-19 severity: chest computed tomography findings. Saudi J Gastroenterol 27(2):105-110. https://doi.org/10.4103/sjg.sjg_540_20

\section{Publisher's Note}

Springer Nature remains neutral with regard to jurisdictional claims in published maps and institutional affiliations.

\section{Submit your manuscript to a SpringerOpen ${ }^{\circ}$ journal and benefit from:}

- Convenient online submission

- Rigorous peer review

- Open access: articles freely available online

- High visibility within the field

- Retaining the copyright to your article

Submit your next manuscript at $\boldsymbol{\nabla}$ springeropen.com 